\title{
TOlERANCE OF EUCALYPT (Eucalyptus spp.) SEedlings to IMAZAPYR IN NUTRITIVE SOLUTION ${ }^{1}$
}

\author{
Tolerância de Mudas de Eucalipto (Eucalyptus spp.) ao Imazapyr, em Solução Nutritiva
}

\author{
SILVA, C.M.M. ${ }^{2}$, FERREIRA, L.R. ${ }^{3}$, FERREIRA, F.A. ${ }^{3}$ and MIRANDA, G.V. ${ }^{3}$
}

\begin{abstract}
Imazapyr has presented excellent results in controlling coppices in stand reforms of eucalypt forests, despite differences in the efficacy levels. To find out whether these different responses are caused by the genetic variability of the cultivated materials, two experiments were carried out under greenhouse conditions with different imazapyr doses in a hydroponic system in plastic vases containing 2,500 $\mathrm{mL}$ solution. The clones IEF-1 (Eucalyptus grandis x Eucalyptus sp. hybrid), GE 463 (E. urophylla x E. grandis), and MN 445 (E. grandis x Eucalyptus sp. hybrid) were used in the first assay, and IEF-1, IEF-2 (E. grandis $\mathrm{x}$ E. urophylla) $\mathrm{x}$ Eucalyptus sp. hybrid) and the clones 129 and 7182 (E. grandis $\mathrm{x}$ Eucalyptus sp. hybrids) in the second assay. Thirty days after transplanting the seedlings to a nutritive solution, imazapyr was applied to the solution at doses of $0.00,0.05,0.10$, $0.20,0.40,0.80,1.60$ and $3.20 \mu \mathrm{L} \mathrm{L}^{-1}$. Clone $\mathrm{GE} 463$ proved to be more tolerant to imazapyr than clones IEF-1 and MN 445 in the first assay; however, in the second, clone 7182 was the most tolerant. Thus, doses should also be differentiated when controlling coppices, according to the cultivated clone.
\end{abstract}

Key words: Chopper NA, Eucalyptus grandis, E. urophylla, herbicide, dose-response.

RESUMO - O imazapyr tem apresentado excelentes resultados no controle de brotações na reforma de cultivos florestais com eucalipto, porém têm sido verificados diferentes niveis de eficiência. Com o intuito de averiguar se as diferentes respostas encontradas podem ser devido à variabilidade gênica dos materiais cultivados, foram realizados dois bioensaios em casa de vegetação, utilizando diferentes doses de imazapyr, sob sistema hidropônico (solução de Clark), em vasos plásticos contendo $2.500 \mathrm{ml}$ de solução. No primeiro ensaio trabalhou-se com os clones $I E F-1$ (híbrido de Eucalyptus grandis $x$ Eucalyptus $s p$.), GE 463 (E. urophylla $x$ E. grandis) e MN 445 (híbrido de E. grandis $x$ Eucalyptus sp.) e, no segundo, com IEF-1, IEF-2 (híbrido de (E. grandis $x \boldsymbol{E}$. urophylla) $x$ Eucalyptus sp.) e os clones 129 e 7182 (híbridos de $\mathbf{E}$. grandis $x$ Eucalyptus sp.). Trinta dias após o transplantio das mudas para solução nutritiva, fez-se a aplicação de imazapyr à solução nas doses de 0,00; 0,05; 0,10;0,20; 0,40; 0,80; 1,60; e 3,20 $\mu \mathrm{L} \mathrm{L} \mathrm{L}^{-1}$. O clone GE 463 mostrou-se mais tolerante ao imazapyr que os clones IEF-1 e MN 445, no primeiro ensaio; já no segundo, o clone 7182 foi mais tolerante. Os clones apresentaram comportamento distinto entre si quanto à presença de imazapyr em solução, indicando que para o controle de rebrota as doses também podem ser diferenciadas, de acordo com o clone cultivado.

Palavras-chave: Chopper NA, Eucalyptus grandis, E. urophylla, herbicida, dose-resposta.

Recebido para publicação em 11.8.2004 e na forma revisada em 17.12.2004.

Doutorando, CCTA/LFIT, Universidade Estadual do Norte Fluminense Darcy Ribeiro - UENF, 28013-602 Campos dos Goytacazes-RJ. ${ }^{3}$ Prof. do Dep. de Fitotecnia da Universidade Federal de Viçosa -UFV, 36571-000 Viçosa-MG. 


\section{INTRODUCTION}

Eucalypt (Eucalyptus sp.) was introduced in Brasil in 1903, for commercial purposes by Edmundo Navarro de Andrade at Companhia Paulista de Estrada de Ferro, to supply firewood for the production of ties and telephone poles, due to its adaptability to different climate, soil, and altitude conditions of the state of São Paulo (Filgueiras, 1989). Nowadays, worldwide plantation areas of eucalypt are estimated to exceed 15 million ha, of which approximately $40 \%$ lie in Brazil, where this genus is the most commonly used for reforestation, with distinct economic purposes (SBS, 2003).

In recent years, Brazil has become a great exporter of forest products, on account of its great competitiveness in this field (Silva et al., 1997), and reforestation has become an excellent investment alternative. According to data of the Sociedade Brasileira de Silvicultura (SBS, 2003), reforested areas in Brazil currently amount to 5.0 millions of hectares.

Due to the great demand for exportation and domestic market of paper, cellulose, charcoal, and, more recently, sawmill industries (for furniture making), vast reforested areas need to be maintained at low cost, without affecting forest production, wood quality, or the environment.

One of the most common problems forest sector companies have to tackle with is deciding the most viable alternative for the future conduct of the stand, i.e., wether to renew the present crop or not (Simões, 1981). If the choice is to reform, coppices will have to be controlled to avoid any competitive effect on newly-planted seedlings (in the space between the previous crop rows) (Little et al., 1996). It is preferable to kill stumps before replanting commences as the rapid initial growth of the coppice would require earlier control than for normal weeding operations. The height of the coppice regrowth would require nozzles to be raised during herbicide spraying, thus increasing the risk of seedling damage through spray drift (Morze, 1971). Some of the methods used to control coppicing are: fire (Poggiani et al., 1983); manual removal of the stump's outer bark; grade "bedding", which also marks planting and fertilization rows (Simões, 1981; Ripasa, 1983); mechanized stump extraction (Vieira \& Da Silva, 1983; Ripasa, 1983; Moro et al., 1988; Guerreiro et al., 1990); and herbicide application over cut surface immediately after felling of the trees (Little \& Eccles, 2000). However, according to Christoffoleti et al. (1997), imazapyr can be applied up to 72 hours after felling with high control efficacy. Another form of coppice control without spray drift risks is injecting imazapyr in the tree trunk (Respondovesk, 1999), besides the different efficacy levels have been observed in coppice control after felling the trees.

According to Whitford et al. (1995), coppice control efficacy depends on the species, herbicide, dose, spacing of the injections and season; besides vapor pressure deficit and soil water deficit on the day before application of the herbicide are important. The authors recommend that for stem injection of E. marginata trees, glyphosate at a dose of $20 \mathrm{~g}$ a.i. $\mathrm{m}^{-2}$ of stem basal area be used in winter, spring and autumn, while for E. calophylla, $80 \mathrm{~g}$ a.i. $\mathrm{m}^{-2}$ of glyphosate is recommended for winter and autumn, provided that, for both species to achieve high mortality, vapor pressure deficit on the day prior to stem injection is less than $1.5 \mathrm{kPa}$. Dantas et al. (2001) verified differences in the coppice control of eucalypt clones after insertion and injection of glyphosate into the tree, with nearly 55\% efficacy 90 days after cutting. In species that tolerate "over the top" application (foliar contact of the herbicide), such as some conifers, selectivity is greater in wintertime, when the plant does not present visible growth, i.e., during its dormancy period (Ahrens, 1981) - period in which trees decrease their physiological activities due to unfavorable conditions. Campbell \& Nicol (1998), working with tolerance of tree seedlings to herbicide applied in pre- or post-emergence, noted that Pinus radiata was more tolerant to herbicides in witch Eucalyptus, Acacia and Casuarina species, since $P$. radiata tolerated $0.36 \mathrm{~kg} \mathrm{ha}^{-1}$ a.i. (glyphosate) while other species could only tolerate 0.18 or $0.09 \mathrm{~kg} \mathrm{ha}^{-1}$ a.i. However, some eucalypt species were more tolerant to glyphosate than 
others, e.g., E. viminalis stood to $0.18 \mathrm{~kg} \mathrm{ha}^{-1}$ a.i. without toxicity symptoms, with the same being verified to E. globulus, E. mannifera and E. viminalis, when applied $0.09 \mathrm{~kg} \mathrm{ha}^{-1}$ a.i.

Relative humidity, light intensity, temperature, and physiological activities, such as photosynthate translocation and xylem pressure potential, can influence herbicide uptake and translocation (Radosevich \& Bayer, 1979; King \& Radosevich, 1985), giving rise to variations in the response of each species to herbicide applications (Gratkowski, 1977; Radosevich et al., 1980; Paley \& Radosevich, 1984).

The selectivity mechanism of imazapyr in some species appears to be a consequence of differences in uptake and translocation, and molecule metabolization in relatively immobile and non-toxic compounds, modifying its half-life in the plant (Shaner \& Mallipudi, 1991). Still, in the case of eucalypt, other factors likely to interfere with the herbicide tolerance have not yet been studied, since the license for using this molecule for coppice control in Brazil has only recently been obtained (Cyanamid, 1999).

Thus, the aim of this work was to evaluate the tolerance of Eucalyptus clones to imazapyr.

\section{MATERIAL AND METHODS}

Two assays were carried out under greenhouse conditions, using different doses of imazapyr $(0.00,0.05,0.10,0.20,0.40,0.80$, 1.60 , and $3.20 \mu \mathrm{L} \mathrm{L}^{-1}$ ), which were mixed with the nutritive Clark solution (Clark, 1975) in plastic vases holding 2,500 $\mathrm{ml}$ of the solution. The $\mathrm{pH}$ was corrected every other day to $5.50 \pm 0.10$ with $\mathrm{NaOH}$ or $\mathrm{HCl}$. The vases were painted with silver color on the outer side, and with a double plastic layer, the first black and the other transparent, on the inner side. The vase lids were perforated with holes of 14 and $2 \mathrm{~mm}$; the largest was used to insert the seedlings, and smallest hole to pass an air tube, connected to a compressor with constant airflow, into the solution.

In the first assay, non-commercial seedlings of IEF-1 (E. grandis x Eucalyptus sp. hybrid), and the clones GE 463 (E. urophylla $\mathrm{x}$ E. grandis) and MN 445 (E. grandis $\mathrm{x}$
Eucalyptus sp.) were used. The seedlings were 4-months old and 20 to $25 \mathrm{~cm}$ high, cultivated in a substrate of vermiculite and carbonized rice chaff, in stiff plastic tubes of $55 \mathrm{~cm}^{3}$. Homogeneous seedlings were used for replanting, after washing the root system, whereupon they were immediately transferred to the hydroponic vases. Pipettes applied the herbicide doses 30 days after the seedling transplant. Forty days after the treatment application (DAT), eucalypt toxicity was evaluated by the symptomatic scale of the European Weed Research Council (EWRC, 1964), which attributes grades 1 to 9 , representing toxicities of $0,1-15,16-30,31-$ 45 , 46-60, 61-75, 76-90, 91-99, and 100\%, respectively, where 0 (zero) is the absence of symptoms and 100\% means plant death. Height and dry biomass of the aerial part (DBAP) and roots (DBR) were also evaluated. After separating the aerial part from the roots, these were separately placed in paper bags, placed in a stove with air circulation, and maintained at a temperature of $72 \pm 1{ }^{\circ} \mathrm{C}$ until weight became constant (after approximately 72 hours), for dry biomass determination. The factorial scheme was $3 \times 8$, with three clones and eight herbicide doses.

In the second assay, the same methods described for the first were used, but with a modified hybrid composition: clones 129 and 7182 (E. grandis x Eucalyptus sp. hybrids), and IEF-1 and IEF-2 ((E. urophylla $\mathrm{x}$ E. grandis) $\mathrm{x}$ Eucalyptus sp. hybrid). Seedlings were three months and a half old and 15 to $20 \mathrm{~cm}$ of hight. The factorial scheme was $4 \times 8$, with four clones and eight herbicide doses.

A completely randomized statistical design was used, with eight treatments corresponding to the herbicide doses, in four replications. The obtained data were submitted to the analysis of variance (ANOVA) after verifying the presuppositions (experimental errors must have a normal distribution, a common variance and must not be correlated among them, and the model parameters must be additive) (Demétrio, 1978). After ANOVA (Table 1), a regression analysis was carried out using the log-logistic model to evaluate the dose-response to height (assay 1) and DBR, and logistic model to DBAP and height (assay 2). The statistical software package 
Table 1 - Summary of analysis of variance for plant height (PH), dry biomass of aerial part (DBAP) and dry biomass of roots (DBR) of eucalypt plants under imazapyr doses, in a hydroponic system

\begin{tabular}{|c|c|c|c|c|}
\hline \multirow{2}{*}{ Source of variation } & \multirow{2}{*}{ D.F. } & \multicolumn{3}{|c|}{ Mean squares } \\
\hline & & $\mathrm{PH}$ & DBAP & DBR \\
\hline \multicolumn{5}{|c|}{ First Assay } \\
\hline Genotype & 2 & $26,35042^{\mathrm{ns}}$ & $28,74095 * *$ & $4,978517 * *$ \\
\hline Treatment & 7 & $830,9778^{* *}$ & $537,0937 * *$ & $29,19644 * *$ \\
\hline Genotype x Treatment & 14 & $65,08412^{* *}$ & $33,10273 * *$ & $2,030421 * *$ \\
\hline Residual & 72 & 11,47459 & 2,441989 & 0,2889355 \\
\hline Coef. of variation & - & 7,505 & 13,166 & 16,696 \\
\hline \multicolumn{5}{|c|}{ Second Assay } \\
\hline Genotype & 3 & $945,1536^{* *}$ & $0,7620196^{* *}$ & $0,3428448^{* *}$ \\
\hline Treatment & 7 & $1.163,775^{* *}$ & 1, $1,322194 * *$ & $1,178601^{* *}$ \\
\hline Genotype x Treatment & 21 & $62,30839 * *$ & $0,07007759 * *$ & $0,08063768 * *$ \\
\hline Residual & 96 & 4,736918 & 0,008144170 & 0,008695483 \\
\hline Coef. of variation & - & 8,153 & 22,0972 & 33,875 \\
\hline
\end{tabular}

ns: denotes non-significance by $F$-test at $10 \%$ of probability; $* *$ : denotes significance by $F$-test at $1 \%$ of probability.

Saeg (SAEG, 1993) was run for the analysis of variance, and the SigmaPlot program (SIGMAPLOT, 1997) for the parameter estimation of the regression model.

The adopted log-logistic model - equation 1 (Seefeldt et al., 1995) - has four parameters, where $y_{0}$ is the inferior limit, i.e., the mean response at the highest dose; $a$ is the difference between the superior and the inferior limit, i.e., the evaluated characteristic amplitude between the highest and the lowest dose; and $b$ describes the slope of the curve around $\mathrm{I}_{50}$ (dose with a response of $50 \%$ of inhibition), given by the value $x_{0}$.

$$
y=y_{0}+\frac{a}{1+\left(\frac{x}{y_{0}}\right)}
$$

The logistic model - equation 2 (Finney, 1979; Streibig, 1988; Souza et al., 2000) - has three parameters as follows: $a$ is denominated "saturation level", corresponding to the bioindicator response at the lowest dose; $x_{0}$ is the inflection point of the curve, which corresponds to the value of $\mathrm{I}_{50}$; and $b$ is the slope of the curve around $\mathrm{I}_{50}$.

$$
y=\frac{a}{1+\left(\frac{x}{y_{0}}\right)^{b}}
$$

Planta Daninha, Viçosa-MG, v. 22, n. 4, p. 597-606, 2004

\section{RESULTS AND DISCUSSION}

Clone MN 445 presented a height of 66.7 $\mathrm{cm}$, superior to the IEF-1 with $58.9 \mathrm{~cm}$ and GE 463 with $52.6 \mathrm{~cm}$, in the treatment without herbicide application (Figure 2). However, MN 445 and GE 463, at doses above $0.8 \mu \mathrm{L} \mathrm{L}^{-1}$ a.i., presented similar heights $y_{0}=39.3554$ and 38.0200 , respectively), about $25 \%$ superior to IEF-1 $\left(y_{0}=29.3688\right)$, and, therefore, less sensitive to higher herbicide doses. Thus, hybrid IEF-1 was the most sensitive to imazapyr as the concentrations increased. This fact was observed by the lower plant height of this clone, together with high toxicity, obtaining grades 8 and 9 for the doses 1.6 and $3.2 \mu \mathrm{L} \mathrm{L}^{-1}$ a.i., respectively (Figure $1 \mathrm{~B}$ ).

Clones IEF-1 and GE 463 presented a similar $I_{50}\left(x_{0}=0.2515\right.$ and 0.2548 , respectively), about $75 \%$ above the value found for clone MN $445\left(x_{0}=0.0669\right)$. This means that the dose-effect response in $\mathrm{I}_{50}$ was much more intense in this last one, presenting a higher sensitivity to small increments at doses below $0.4 \mu \mathrm{L} \mathrm{L}^{-1}$ a.i. (Figure 2).

The smallest amplitude between the highest and lowest doses $(a)$, the smallest slope of curve-response $(b)$ and the highest $\mathrm{I}_{50}$ value $\left(x_{0}\right)$ showed that clone GE 463 was the most tolerant to increased herbicide doses, since it presented a smaller effect on the height in relation to clones IEF-1 and MN 445. 

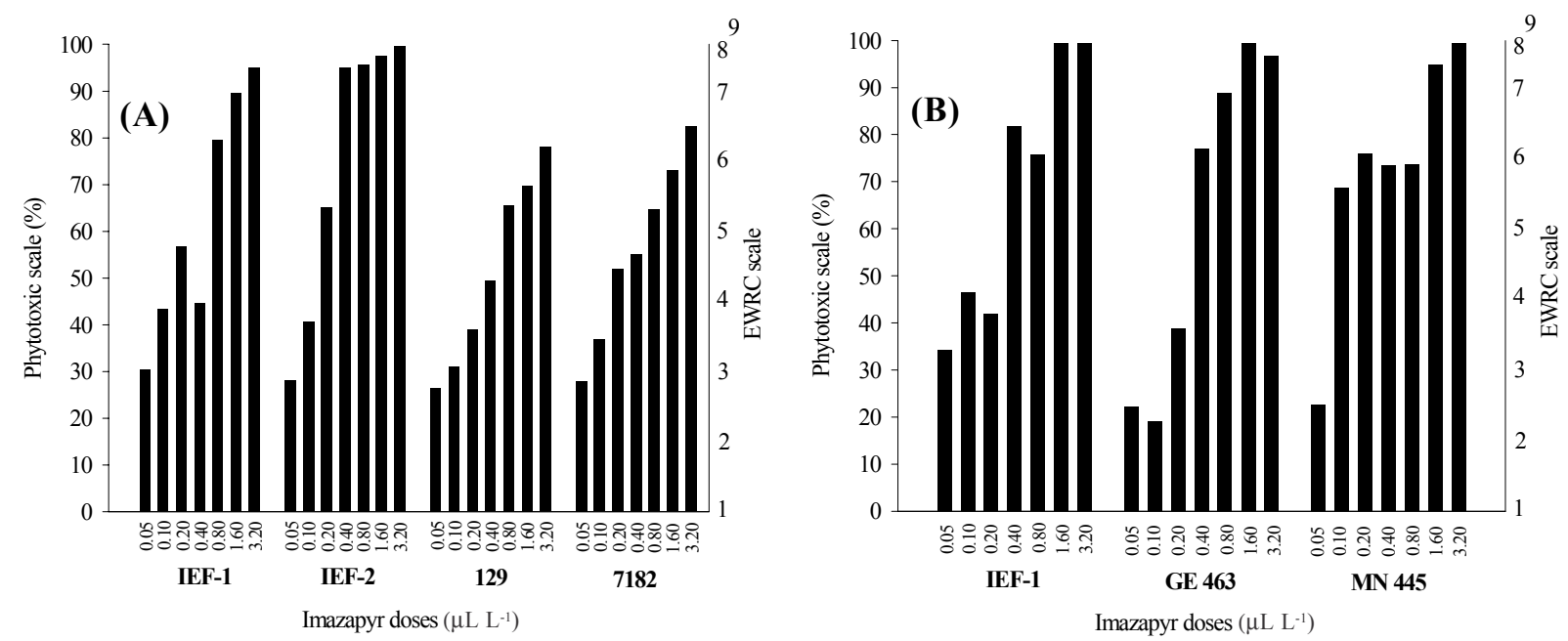

Figure 1 - Percent and grades of toxicity of the eucalypt plants (A - first assay and B - second assay) in relation to imazapyr doses at 40 days after treatment application.
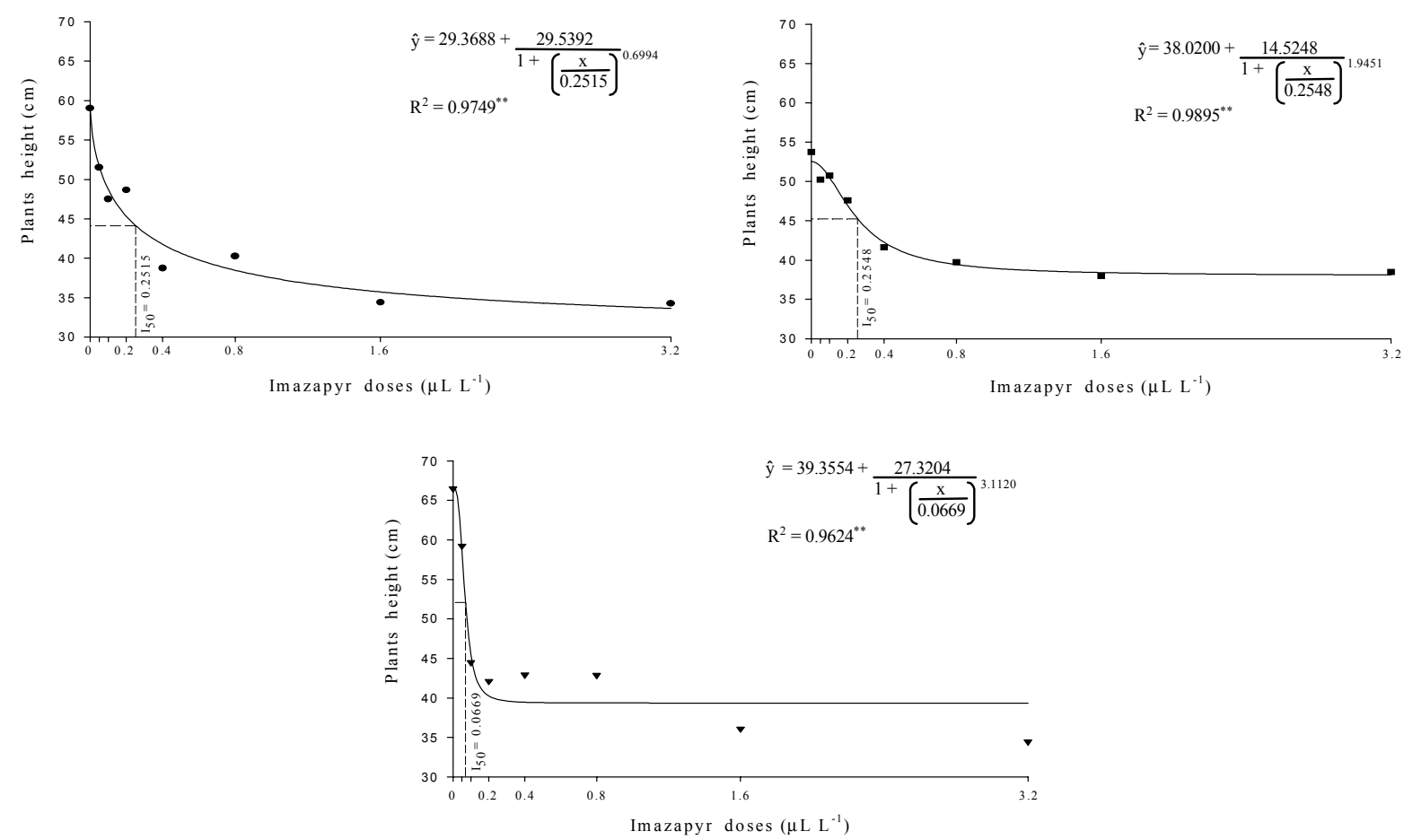

Figure 2 - Dose-response curve of plant height of IEF-1 (•), GE $463(\boldsymbol{\square})$, and MN 445 ( $\boldsymbol{\nabla})$ clones, under increasing doses of imazapyr.

For the dry biomass of the aerial part (Figure 3), clone GE 463 presented an $\mathrm{I}_{50}$ of $0.4603 \mu \mathrm{L} \mathrm{L}^{-1}$ a.i., $63.9 \%$ superior to IEF-1 (with $0.1663 \mu \mathrm{L} \mathrm{L}^{-1}$ a.i.), and $80.8 \%$ superior to MN 445 (with $0.0886 \mu \mathrm{L} \mathrm{L}^{-1}$ a.i.). The latter was more sensitive to small increments of doses up to $0.2 \mu \mathrm{L} \mathrm{L}^{-1}$ a.i. Increased imazapyr concentrations above $1.6 \mu \mathrm{L} \mathrm{L}^{-1}$ a.i. did not interfere with the DBAP growth of clones, since above this dose the plants died (grade 9). Clones GE 463, IEF-1, and MN 445 presented a DBAP of $20.8,25.3$ and $26.4 \mathrm{~g}$ per vase, 
respectively, in the treatment without herbicide application.

The values of the curve slopes $(b)$ around the dose that inhibited $50 \%$ of the aerial part growth indicated a softer slope for clone GE 463, since the tangent line to the curve at the $I_{50}$ value presents a greater angle with the axis of the imazapyr doses, thus expressing, together with the $I_{50}$ value, a greater tolerance of this clone to imazapyr (Figure 3).

Clones GE 463 and MN 445 presented similar behaviors of the dry root biomass (Figure 4) in relation to the control (zero dose) as well as to doses above $0.8 \mu \mathrm{L} \mathrm{L}^{-1}$ a.i. However, the first presented an $\mathrm{I}_{50}\left(0.6065 \mu \mathrm{L} \mathrm{L}^{-1}\right.$ a.i. $)$ of about $100 \%$ above the value found for IEF-1 (0.3186 $\mu \mathrm{L} \mathrm{L}^{-1}$ a.i.) and MN $445\left(0.3657 \mu \mathrm{L} \mathrm{L}^{-1}\right.$ a.i.), which expressed a greater imazapyr tolerance of GE 463 compared to the others.

The clones used in the second assay presented similar heights (Figure 5) in the absence of imazapyr, but clones IEF-1 and IEF2 presented a reduced growth in height as the herbicide concentrations increased, with the effect being more evident for the IEF-2 hybrid, because it presented a smaller $\mathrm{I}_{50}$ value $\left(x_{0}=\right.$ $0.1180)$. Clones 7182 and 129 were more tolerant to imazapyr since the applied doses were insufficient to determine $\mathrm{I}_{50}$, besides obtaining less grades of toxicity than the IEF1 and IEF-2 clones (Figure 1A).

It was necessary to transform the DBAP and DBR by the equation $\mathrm{x}_{t}=\log \mathrm{x}$ (where $\mathrm{x}$ is the studied variable and $x_{t}$ the transformed one) to obtain a normal data distribution.

The Log of the dry biomass yield of the aerial part (Figure 6) was similar to the clones IEF-1 (with 0.9816) and 7182 (with 0.9528) in the herbicide absence; however, the $\mathrm{I}_{50}$ value was about three times higher for $7182\left(x_{0}=\right.$ $0.6043)$ in relation to IEF-1 $\left(x_{0}=0.2384\right)$, displaying a greater tolerance of this clone at doses below $0.8 \mu \mathrm{L} \mathrm{L}^{-1}$ a.i. The superiority of this clone was also verified, for the same reasons, when compared to the $\mathrm{I}_{50}$ value of $\mathrm{IEF}$ $2\left(x_{0}=0.1149\right)$ and $129\left(x_{0}=0.0756\right)$, since it
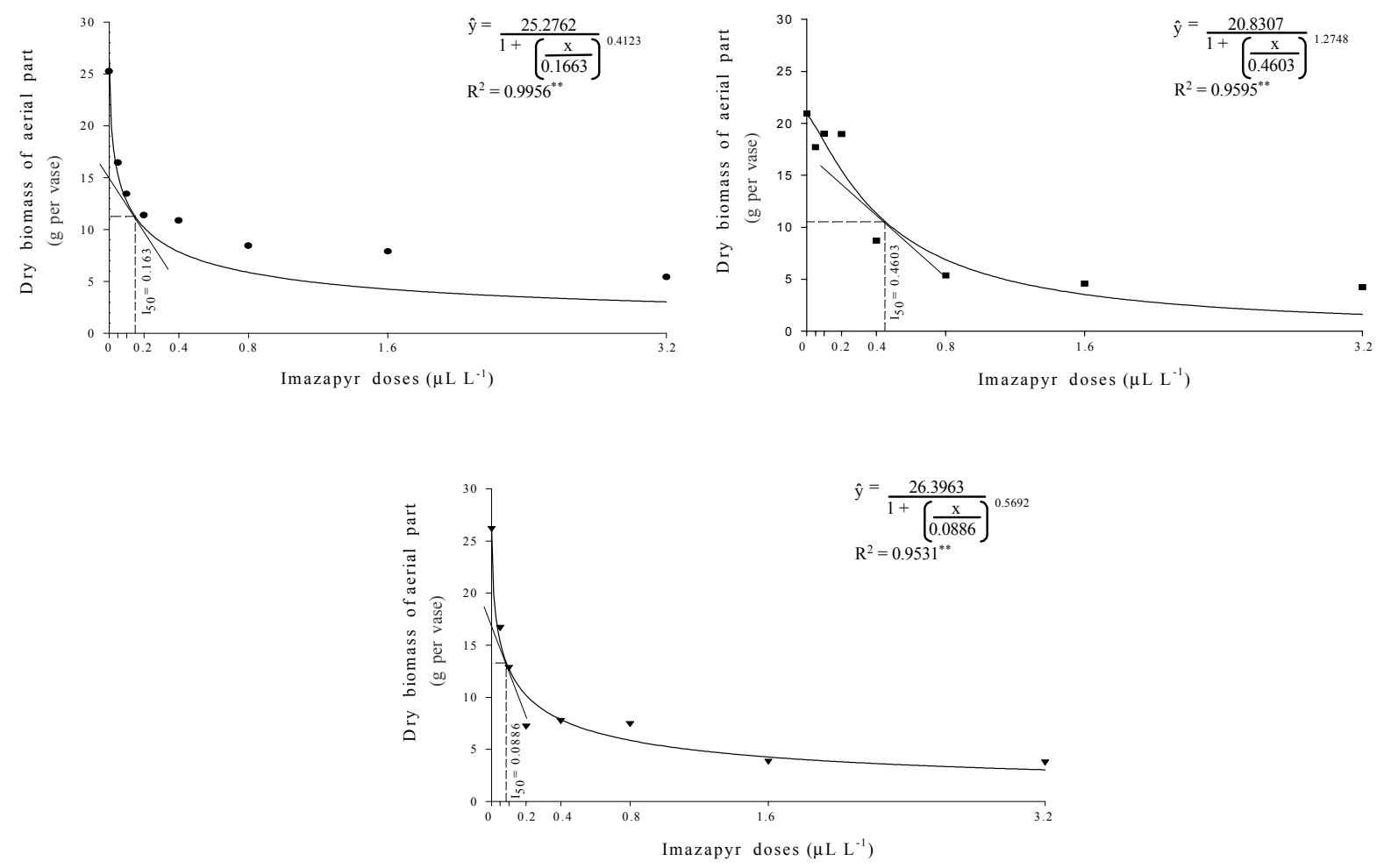

Figure 3 - Dose-response curve of dry biomass of aerial part of IEF-1 (•), GE $463(\boldsymbol{\nabla})$, and MN 445 ( $\boldsymbol{\nabla}$ ) clones, under increasing doses of imazapyr. 

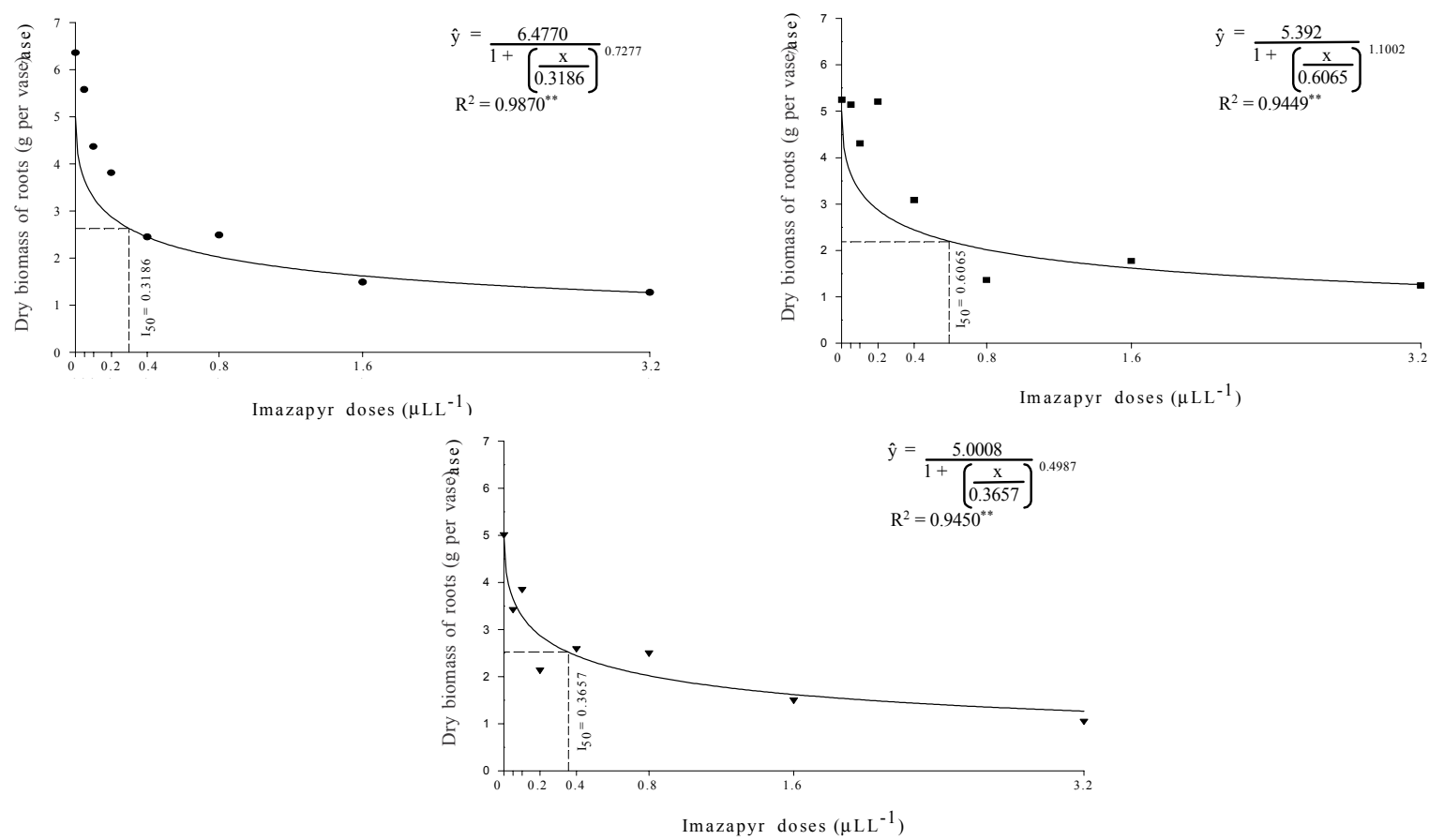

Figure 4 - Dose-response curve of dry biomass of roots of IEF-1 (•), GE 463 ( $\bullet$ ), and MN 445 ( $\boldsymbol{\nabla}$ ) clones, under increasing doses of imazapyr.
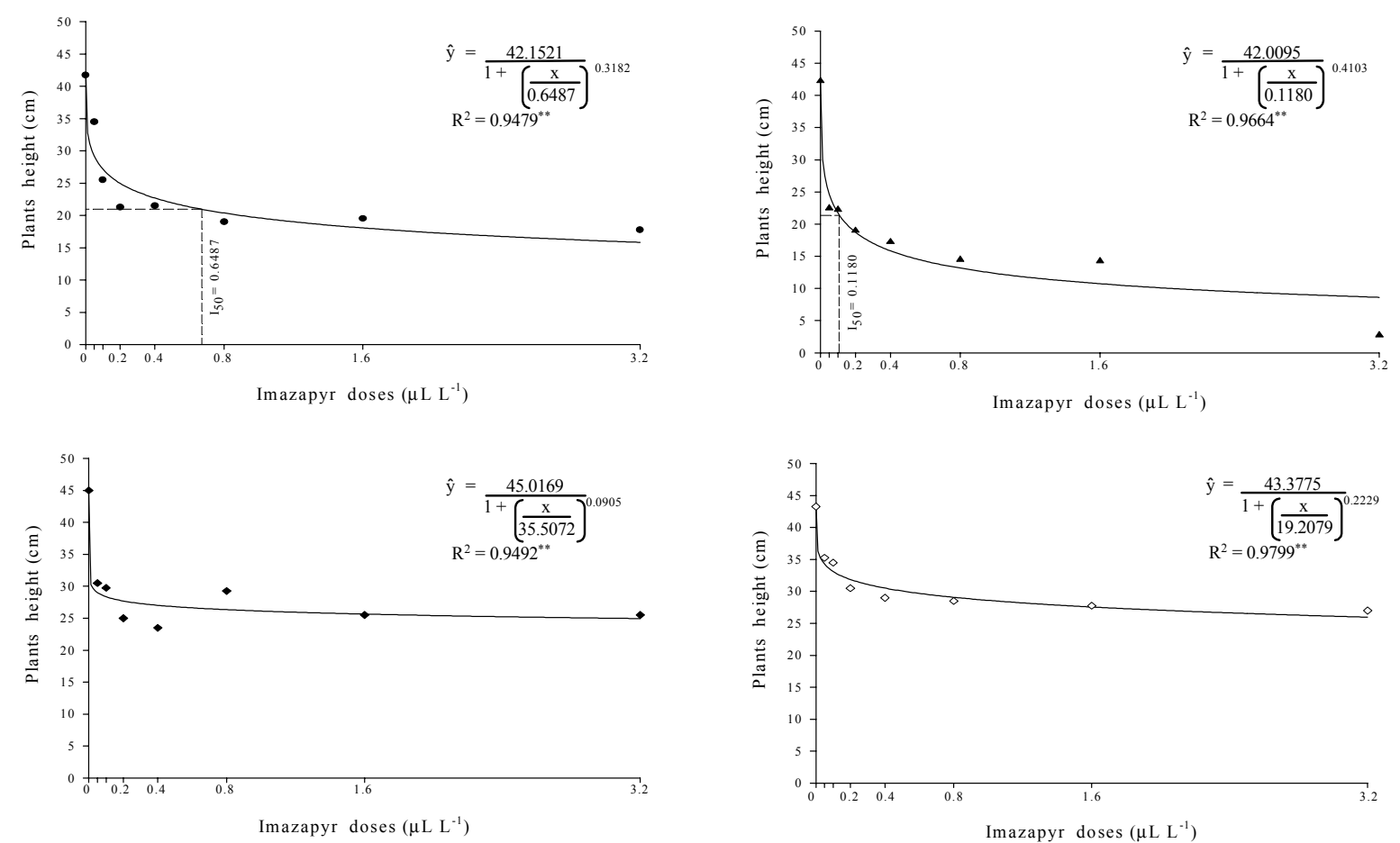

Figure 5 - Dose-response curve of plant height of IEF-1 $(\bullet)$, IEF-2 $(\boldsymbol{\Delta}), 129(\diamond)$ and $7182(\diamond)$ clones, under increasing doses of imazapyr. 
was five times greater than the first and eight times greater than the second. These two last clones, besides presenting a smaller DBAP under imazapyr absence and smaller $I_{50}$ values, also presented greater effect of the DBAP dose-response at doses above $0.8 \mu \mathrm{L} \mathrm{L}{ }^{-1}$ a.i.

After analyzing the Log of the dry root biomass (DBR), it was verified that clone 7182 also showed more tolerance to imazapyr at doses below $0.4 \mu \mathrm{L} \mathrm{L}^{-1}$ a.i., presenting a greater $\mathrm{I}_{50}$ value among the hybrids, because increases at doses above this reduced the DBAP growth for the clones IEF-1 and 7182 (Figure 7).

The clones GE 463 and 7182 own some detoxification mechanism for the imazapyr molecule, which might involve oxidation, reduction, and/or, herbicide hydrolysis (Shaner \& Mallipudi, 1991), or else, a smaller uptake amount of the molecule present in solution, which could have caused increased tolerance of these clones to imazapyr, compared to the others. Green et al. (1992) verified differences of glyphosate uptake and translocation when studying four forest
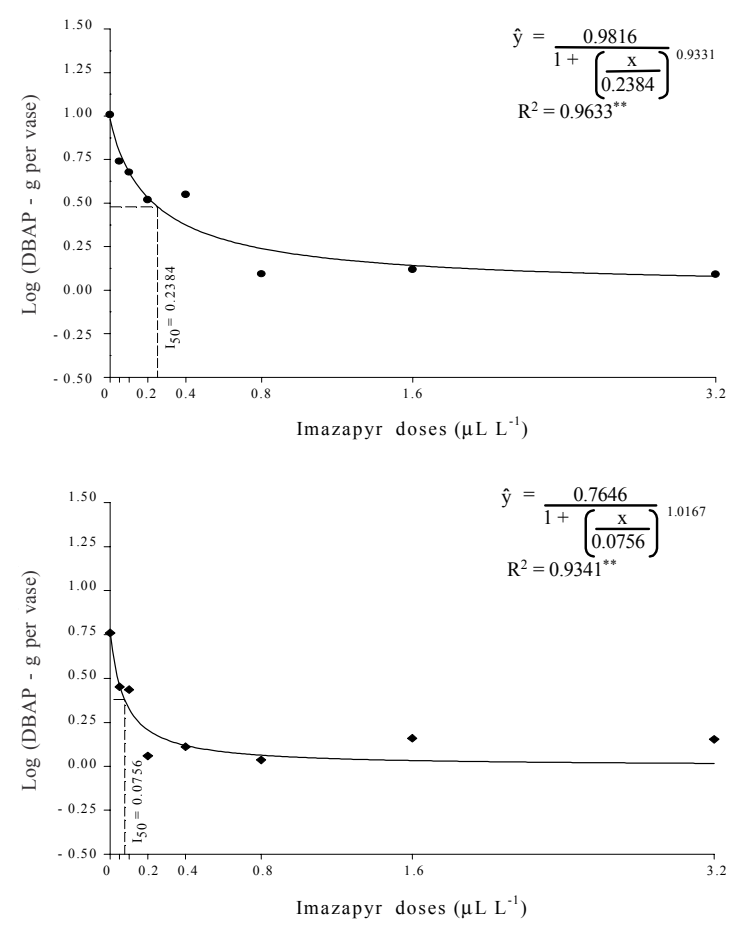

Figure 6 - Dose-response curve of Log of dry aerial part biomass (DBAP) of IEF-1 $(\bullet)$, IEF-2 (४), $129(\diamond)$, and $7182(\diamond)$ clones, under increasing doses of imazapyr.

Planta Daninha, Viçosa-MG, v. 22, n. 4, p. 597-606, 2004
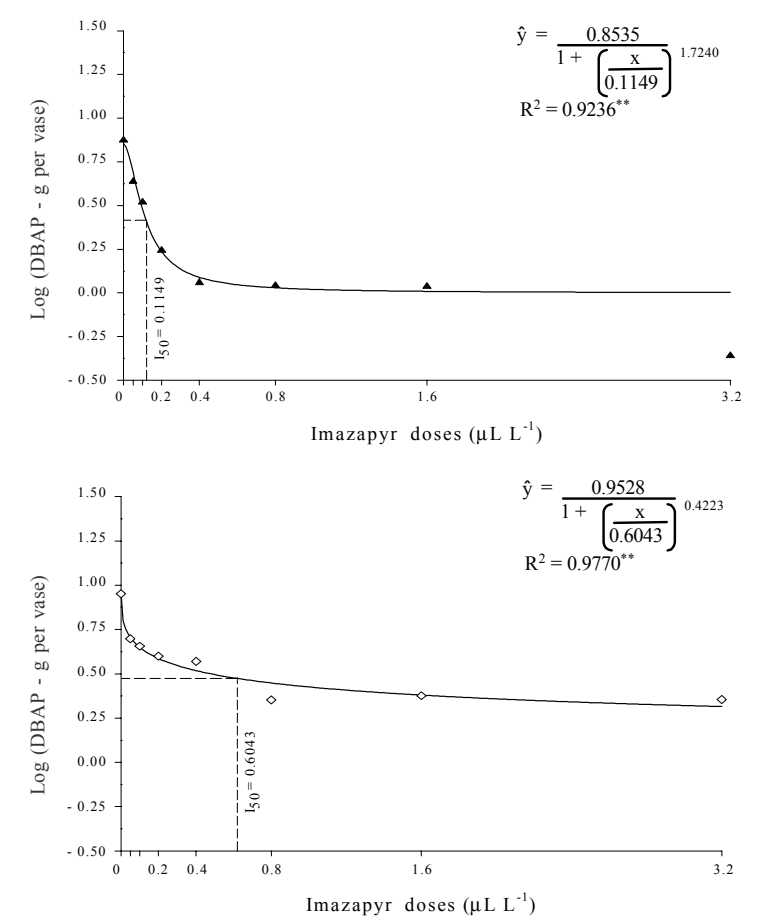

species: loblolly pine (Pinus taeda L.) and yaupon (Ilex vomitaria (L.) Ait.) were more tolerant to this herbicide than to red maple (Acer rubrum L.) and white oak (Quercus alba) due to a lower molecule uptake. Moreover, Q. alba was more tolerant than A. rubrum, due to its ability to accumulate greater quantities of glyphosate in the roots.

Under the present experimental conditions, our results allow the following conclusions: the estimate of the $I_{50}$ value varies according to the evaluated characteristic; and the efficacy of imazapyr used in eucalypt to control coppices may vary according to the clone used, since clones GE 463 and 7182 were more tolerant to imazapyr compared to the others.

The selection of more tolerant clones is very interesting when it is necessary to make chemical weed control after planting eucalypt seedlings, since the herbicide would control the weeds without killing the seedlings. However, when opting for sprouting control after cut-stumps, the use of high doses of herbicide is required or less tolerant clones must be used at planting. 

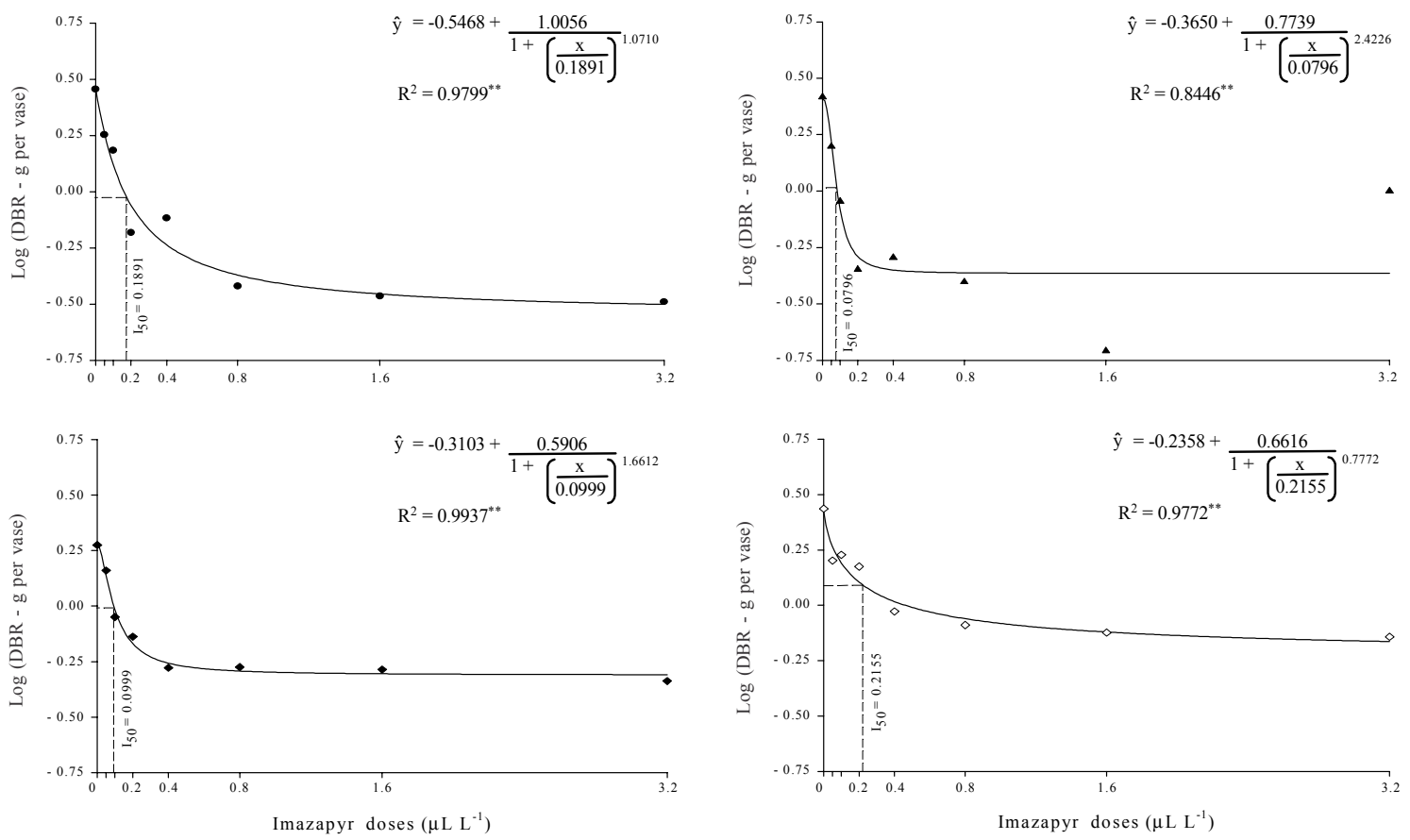

Figure 7 - Dose-response curve of Log of dry biomass of roots (DBR) of IEF-1 (•), IEF-2 (४), $129(\diamond)$, and $7182(\diamond)$ clones, under increasing doses of imazapyr.

\section{ACKNOWLEDGEMENTS}

The authors would like to thank Leticia M. Medeiros for the English translation. Thanks are also given to Mannesmann Florestal and Cenibra companies, and Instituto Estadual de Floresta for providing the eucalypt seedlings, and the Department of Plant Science of the Universidade Federal de Viçosa for supporting this work.

\section{LITERATURE CITED}

AHRENS, J. F. Tolerance of dormant Fraser fir to postemergence herbicides. Proc. North. Weed Sci. Soc., v. 35, n. 203-206, 1981.

CAMPBELL, M. H.; NICOL, H. I. Tolerance of tree seedlings to pre- and post-emergence herbicides. In: AUSTRALIAN AGRONOMY CONFERENCE, 9., 1998, Wagga Wagga. Proceedings... Wagga Wagga: NSW Agricultue, 1998. Disponível em: $<$ http:// www.regional.org.au/au/asa/1998/3/ 053campbell.htm\#P1_65>. Acesso em: 06 ago. 2004.

CLARK, R. B. Characterization of phosphatase of intact maize roots. J. Agric. Food Chem., v. 23, n. 3, p. 458-460, 1975.
CYANAMID. Lançamento do herbicida Chopper NA. Rio de Janeiro: Cyanamid Company, 1999. CD-ROM

DANTAS, F. W. F.; SOUZA, A. J.; DI CIERRO, A. Controle da rebrota de eucalipto em área de reflorestamento. In: SEMINÁRIO NACIONAL SOBRE HERBICIDAS E TECNOLOGIA DE APLICAÇÃO EM FLORESTAS, 1., 1999, Viçosa, MG. Anais... Viçosa: SIF, 2001. p. 29-44.

DEMÉTRIO, C. G. B. Transformação de dados: efeitos sobre a análise de variância. 1978. 113 f. Dissertação (Mestrado em Experimentação e Estatística) - Escola Superior de Agricultura “Luiz de Queiroz”, Piracicaba, 1978.

EWRC. Report of the 3rd and 4th meetings of EWRC. Committees of Methods in Weed Research. Weed Res., v. 4, p. $88,1964$.

FILGUEIRAS, J. F. Análise sócio-econômica dos reflorestamentos com eucalipto, no distrito federal do Vale do Rio Doce, Minas Gerais. 1989. 72 f. Dissertação (Mestrado em Engenharia Florestal) - Universidade Federal de Viçosa, Viçosa, 1989.

FINNEY, D. J. Bioassay and the practice of statistical inference. Int. Stat. Rev., v. 47, n. 1, p. 1-12, 1979.

GUERREIRO, C. A.; ROMERO, A.; WADOUSKI, L. H. Desenvolvimento de um rebaixador mecanizado de cepas. In: CONGRESSO FLORESTAL BRASILEIRO, 6., 1990, Campos do Jordão, SP. Anais... Campos do Jordão: SBS, 1990. v. 3, p. 4-6.

Planta Daninha, Viçosa-MG, v. 22, n. 4, p. 597-606, 2004 
GRATKOWSKI, H. J. Seasonal effects of phenoxy herbicides on ponderosa pine and associated brush species. For. Sci., v. 23, n. 1, p. 3-12, 1977.

GREEN, T. H. et al. Uptake and translocation of $\left[{ }^{14} \mathrm{C}\right]$ glyphosate in four woody plant species. Can. J. For. Res., v. 22, n. 6, p. 785-789, 1992.

HARCOURT, R. L. et al. Insect- and herbicide-resistant transgenic eucalypts. Mol. Breeding, v. 6, n. 3 , p. 307315,2000 .

KING, S. P.; RADOSEVICH, S. R. Herbicide tolerance in relation to growth and stress in conifers. Weed Sci., v. 33, n. 4 , p. $472-478,1985$

LITTLE, K. M.; ECCLES, N. S. Control of Eucalyptus grandis cut-stumps of single-stem origin. Southern Afri. For. J., v. 187, p. 45-49, 2000.

LITTLE, K. M. et al. Growth of eucalypts on slash managed and burned sites in Zululand. ICFR Bull. Series, n. 3/96, p. 4-5, 1996.

MORO, L. et al. Rebaixamento de tocos de eucalipto. Circ. Téc. IPEF, v. 165, p. 1-3, 1988.

MORZE, J. Chemical control of Eucalyptus species. For. S. Afri., v. 12, n. 1, p. 49-53, 1971.

PALEY, S. M.; RADOSEVICH, S. R. Effect of physiological status and growth of ponderosa pine (Pinus ponderosa) and greenleaf manzanita (Arctostaphylos patula) on herbicide selectivity. Weed Sci., v. 32, n. 3, p. 395-402, 1984.

POGGIANI, F.; REZENDE, G. C.; SUITER FILHO, W. Efeitos do fogo na brotação e crescimento de Eucalyptus grandis após o corte raso e alterações nas propriedades do solo. IPEF, v. 24, p. 33-42, 1983.

RADOSEVICH, S. R.; BAYER, D. E. Effect of temperature and photoperiod on triclopyr, picloram, and 2,4,5-T translocation. Weed Sci., v. 27, n. 1, p. 22-27, 1979.

RADOSEVICH, S. R. et al. Season tolerance of six coniferous species to eight foliage-active herbicides. For. Sci., v. 26, n. 1, p. 3-9, 1980.

RESPONDOVESK, R. J. Controle de brotações em reformas de plantações florestais na RIPASA. In: SEMINÁRIO SOBRE CONTROLE DE PLANTAS INFESTANTES EM ÁREAS FLORESTAIS, 1., 1999, Piracicaba. Anais... Piracicaba: Escola Superior de Agricultura "Luiz de Queiroz" 1999. CD ROM
RIPASA. Reforma de povoamentos de Eucalyptus spp.estudo de alternativas operacionais. In: CONGRESSO FLORESTAL BRASILEIRO, 4., 1982, Belo Horizonte. Anais... Belo Horizonte: SBS, 1983. p. 269-273.

SAEG. Sistema para Análises Estatísticas: versão 5.0. Viçosa: Fundação Arthur Bernardes, 1993.

SOCIEDADE BRASILEIRA DE SILVICULTURA - SBS Área plantada com pinus e eucaliptos no Brasil.

Disponível em: <http://www.sbs.org.br/area_plantada.htm>. Acesso em: 06 jun. 2003.

SEEFELDT, S.; JENSEN, J. E.; FUERST, E. P. Log-logistic analysis of herbicide dose-response relationships. Weed Technol., v. 9, n. 2, p. 218-227, 1995.

SHANER, D. L.; MALLIPUDI, N. M. Mechanisms of selectivity of the imidazolinones. In: SHANER, D. L.; O'CONNOR, S. L. (Eds.). The imidazolinone herbicides. Boca Raton: CRC Press, 1991. p. 91-102.

SIGMAPLOT. Scientific graphing software: version 4.0, SPSS Inc. 1997.

SILVA, M. L. et al. Viabilidade econômica do reflorestamento do eucalipto consorciado com a cultura do feijão: um estudo de caso. R. Árvore, v. 21, n. 4, p. 527-35, 1997.

SIMÕES, J. W. Formação, manejo e exploração de florestas com espécies de rápido crescimento. Brasília: IBDF, 1981. $74 \mathrm{p}$.

SOUZA, A. P. et al. Lixiviação de glyphosate e imazapyr em solos com diferentes texturas e composição química: IMétodo do Bioensaio. Planta Daninha, v. 18, n. 1, p. 5-16, 2000.

STREIBIG, J. C. Herbicide bioassay. Weed Res., v. 28, n. 6, p. $479-484,1988$

VIEIRA, S. B.; DA SILVA, E. F. Teste de máquina LEVCO 540 na eliminação de tocos de eucaliptos. In: CONGRESSO FLORESTAL BRASILEIRO, 4., 1982, Belo Horizonte. Resumos... São Paulo: SBS, 1983. p. 608.

WHITFORD, K. R. et al. Mortality of Eucalyptus marginata (jarrah) and E. calophylla (marri) trees following stem injection: effects of herbicide, dose, season, and spacing of injections. Aust. For., v. 58, n. 4, p. 172-178, 1995. 